Article

\title{
Characterization of Barnyard Millet Starch Films Containing Borage Seed Oil
}

\author{
Thi Luyen Cao, So-Young Yang and Kyung Bin Song * \\ Department of Food Science and Technology, Chungnam National University, Daejeon 34134, Korea; \\ ctluyenagu@gmail.com (T.L.C.); sygrim@gmail.com (S.-Y.Y.) \\ * Correspondence: kbsong@cnu.ac.kr; Tel.: +82-42-821-6723; Fax: +82-42-825-2664
}

Academic Editor: Isabel Coelhoso

Received: 22 September 2017; Accepted: 31 October 2017; Published: 1 November 2017

\begin{abstract}
In this study, barnyard millet starch (BMS) was used to prepare edible films. Antioxidant activity was conferred to the BMS film by incorporating borage seed oil (BO). The physical, optical, and thermal properties as well as antioxidant activities of the films were evaluated. The incorporation of BO into the BMS films decreased the tensile strength from 9.46 to $4.69 \mathrm{MPa}$ and increased the elongation at break of the films from $82.49 \%$ to $103.87 \%$. Water vapor permeability, water solubility, and moisture content of the BMS films decreased with increasing BO concentration, whereas Hunter $b$ value and opacity increased, $L$ and $a$ values of the films decreased. The BMS films containing $\mathrm{BO}$ exhibited antioxidant activity that increased proportionally with increased $\mathrm{BO}$ concentration. In particular, the BMS film with 1.0\% BO exhibited the highest antioxidant activity and light barrier properties among the BMS films. Therefore, the BMS films with added BO can be used as an antioxidant packaging material.
\end{abstract}

Keywords: antioxidant activity; edible films; essential oils; starch

\section{Introduction}

Biodegradable films have been applied in food packaging to resolve problems related to environmental impact [1]. Among bio-materials used for films, starch is popular in edible film production because of its widespread distribution in nature, ease of isolation, and low cost [2]. Recent studies have been conducted to improve the functional properties of starch films, such as antimicrobial, antioxidant activities, and light barrier properties [3]. In addition, economic and environmental benefits from utilizing agricultural byproducts or underutilized natural materials for film preparation have attracted attention for edible film production $[4,5]$.

Barnyard millet is a cereal cultivated in Asian countries for human food or animal feed [6]. Owing to its extreme hardiness, this cereal is appreciated as a dominant crop on harsh lands [7]. Barnyard millet contains starch $(66 \%)$, protein $(15 \%)$, lipid $(7 \%)$, and various micronutrients $[8,9]$. However, this cereal has a hard pericarp and contains high amylose content, which reduces its culinary and organoleptic properties [10]. In addition, this grain possesses low digestibility [11]. These disadvantages have limited the popular consumption of this grain and confined it as a coarse food [10], but starch containing high amylose content is considered a raw material for edible films with good oxygen barrier properties [12].

Fatty acids have been incorporated into starch films as a chemical modifier [13,14]. In particular, the incorporation of fatty acids decreases the hydrophilicity of starch films. Borage (Borago officinalis L.) seed consists of various bioactive compounds including fatty acids and phenolic substances. Mhamdi et al. [15] investigated fatty acid contents in ripe borage seed and found that unsaturated fatty acids accounted for more than $80 \%$ of total fatty acids, while rosmarinic and p-coumaric acids were dominant phenolic substances. In addition, Khan and Shahidi $[16,17]$ reported the presence of 
$\delta$-tocopherols and $\gamma$-tocopherols—compounds with strong antioxidant activities-in borage seed oil. Borage seed oil (BO) is odorless, and it can be used as a chemical modifier to improve the functional properties of films prepared from the underutilized barnyard millet starch (BMS). Moreover, BMS films containing BO have not been studied. Therefore, the objective of this study was to develop BMS films and characterize the physical, optical, and thermal properties as well as antioxidant activity of the BMS films incorporated with BO.

\section{Materials and Methods}

\subsection{Materials}

Barnyard millet (Echinochloa utilis) was purchased from Grainlife Co., Goesan, Korea. Commercial BO (purity 100\%) was provided by The Witch Company (Seoul, Korea). Sorbitol and Tween 80 were obtained from Sigma-Aldrich Chemical Co., St. Louis, MO, USA.

\subsection{Starch Extraction}

Barnyard millet grains were pulverized in a Waring blender (Osaka Chemical Co., Osaka, Japan), then soaked in $0.3 \% \mathrm{NaOH}$ solution (flour: $\mathrm{NaOH}$ solution, 1:6, $w / v$ ), homogenized at $12,000 \mathrm{rpm}$ for $5 \mathrm{~min}$, incubated at $4{ }^{\circ} \mathrm{C}$ for $24 \mathrm{~h}$ with constant stirring at $300 \mathrm{rpm}$, sieved through a 200-mesh screen, and centrifuged at $10,000 \times g$ for $15 \mathrm{~min}$. The precipitate was obtained after removing the dark yellow layer from the surface. Afterwards, the precipitate was washed with distilled water, neutralized to a $\mathrm{pH}$ of 7.0, and centrifuged at $10,000 \times g$ for $15 \mathrm{~min}$. The extracted starch was dried on a clean bench at $25^{\circ} \mathrm{C}$ for $18 \mathrm{~h}$. Finally, dried starch was ground using a mortar and pestle, then sieved through a 200-mesh screen.

\subsection{Preparation of the BMS Films}

BMS $(3.5 \%, w / v)$ suspension was prepared by dispersing starch in distilled water. Sorbitol ( $50 \%$ of starch weight, $w / w)$ was added to the starch suspension as a plasticizer, and the suspension was heated at $95{ }^{\circ} \mathrm{C}$ for $20 \mathrm{~min}$ with constant stirring at $260 \mathrm{rpm}$. The film-forming solution was prepared by adding $\mathrm{BO}$ at different concentrations $(0.2 \%, 0.4 \%, 0.6 \%, 0.8 \%$, and $1 \%$ of film-forming solution, $w / v)$ and Tween $80(10 \%$ of $\mathrm{BO}, w / w)$, followed by homogenization at $12,000 \mathrm{rpm}$ for $5 \mathrm{~min}$. A film-forming solution without $\mathrm{BO}$ and Tween 80 was used as the control film. The film-forming solutions were casted on plates and dried at $25^{\circ} \mathrm{C}$, relative humidity $50 \%$ for $15 \mathrm{~h}$.

In this study, Tween 80 was used as a surfactant in the BMS film containing BO. The effect of Tween 80 on the physical and optical properties of the films was evaluated, and the obtained results showed that the amount of Tween 80 used did not affect the physical and optical properties of the films.

\subsection{Determination of Physical Properties of the BMS Films}

An Instron machine (M250-2.5 CT, The Testometric Company Ltd., Lancashire, UK) was used to determine tensile strength (TS) and elongation at break (E). Film sheets $(2.54 \mathrm{~cm} \times 8 \mathrm{~cm})$ were prepared and fitted into the grips with an initial clearance of $5 \mathrm{~cm}$. The stretching was performed at a speed of $50 \mathrm{~cm} / \mathrm{min}$. At least five sheets of each sample were measured to evaluate TS and E. These two parameters were calculated based on the equations described by Yang et al. [18].

Five pieces of each film $(2 \mathrm{~cm} \times 2 \mathrm{~cm})$ were dried at $105^{\circ} \mathrm{C}$ for $24 \mathrm{~h}$ to determine the moisture content (MC) of the films. MC was calculated using Equation (1).

$$
\operatorname{MC}(\%)=\left(\frac{W_{0}-W}{W_{0}}\right) \times 100
$$

where $W_{0}$ is the initial weight of the film and $W$ is the weight of the film after drying for $24 \mathrm{~h}$.

To determine water solubility (WS), dry films were gently shaken in 50-mL tubes containing $20 \mathrm{~mL}$ deionized water at $25^{\circ} \mathrm{C}$ for $24 \mathrm{~h}$. The films were then placed on aluminum dishes and dried 
at $105{ }^{\circ} \mathrm{C}$ for $24 \mathrm{~h}$. The WS was expressed as the percentage of the decrease in film weight. Five film squares $\left(4 \mathrm{~cm}^{2}\right)$ were analyzed for each type of film.

The water vapor permeability (WVP) of the films was evaluated at $25^{\circ} \mathrm{C}$ and relative humidity of $50 \%$, according to the method described by Song et al. [19]. The experiment was carried out in triplicate.

\subsection{Measurement of Optical Properties}

Color and opacity of the films were determined based on the method described by Kim et al. [20]. The $L, a$, and $b$ values of the white standard plate were $96.79,-0.15$, and 2.03 , respectively.

\subsection{Determination of Antioxidant Activities}

Ferric reducing antioxidant power (FRAP) and 2,2'-azino-bis (3-ethyl-benzothiazoline-6-sulfonic acid) (ABTS) radical scavenging assays were carried out to determine the antioxidant activity of the films. The film extract solution for the assays was obtained by shaking tubes containing $19.5 \mathrm{~mL}$ deionized water and $0.5 \mathrm{~g}$ of the films $(0.3 \mathrm{~cm} \times 0.3 \mathrm{~cm})$ at $37^{\circ} \mathrm{C}, 150 \mathrm{rpm}$ for $30 \mathrm{~min}$, followed by centrifugation at $10,000 \times g$ for $5 \mathrm{~min}$ to remove solid materials. FRAP reagent was prepared according to methods described by Da Silva and Jorge [21]. A mixture of FRAP reagent $(5 \mathrm{~mL})$ and film sample $(2 \mathrm{~mL}$ ) was placed in the dark for $30 \mathrm{~min}$ and centrifuged at $3000 \times \mathrm{g}$ for $3 \mathrm{~min}$ to eliminate precipitate. The absorbance of the supernatant was measured at $593 \mathrm{~nm}$. The ABTS test was carried out according to the method described by Lee et al. [22]. A mixture containing $4 \mathrm{~mL}$ of ABTS reagent and $1.8 \mathrm{~mL}$ of film sample was prepared to measure the absorbance at $734 \mathrm{~nm}$.

\subsection{Scanning Electron Microscopy (SEM)}

Microscopic images of the films were obtained using a focused beam of high-energy electrons generated by a scanning electron microscope (LYRA3 XMU; Tescan, Warrendale, PA, USA). An accelerating voltage of $5.0 \mathrm{kV}$ was used, and magnifications of $3000 \times$ and $2000 \times$ were utilized to examine surface and cross-section microstructures, respectively.

\subsection{Differential Scanning Calorimetry (DSC)}

DSC was carried out with a Mettler Toledo DSC 1 (Mettler Toledo, Schwerzenbach, Switzerland) with $10{ }^{\circ} \mathrm{C} / \mathrm{min}$ as the heating rate from 50 to $200{ }^{\circ} \mathrm{C}$ to determine the melting temperature $\left(T_{\mathrm{m}}\right)$ and fusion enthalpy $(\Delta H)$ of the films $(10 \pm 0.35 \mathrm{mg})$.

\subsection{Statistical Analysis}

Significant differences among experimental data were determined by analysis of variance and Duncan's multiple range tests $(p<0.05)$ using the SAS program (SAS Institute, Cary, NC, USA). The results were expressed as the mean \pm standard deviation.

\section{Results and Discussion}

\subsection{Physical Properties of the BMS Films}

Prior to the measurement of physical properties of the BMS films containing BO, the effect of Tween 80 on the physical and optical properties of the BMS films was examined. The BMS films with sorbitol and Tween 80 only at $10 \%(w / w)$ of $1.0 \%$ BO as a maximum amount used in this study had the TS, E, WVP, and opacity of $9.24 \pm 0.41 \mathrm{MPa}, 83.56 \% \pm 2.85 \%,(4.48 \pm 0.19) \times 10^{-9} \mathrm{~g} / \mathrm{m} \cdot \mathrm{s} \cdot \mathrm{Pa}$, and $0.55 \pm 0.06 \mathrm{~A} / \mathrm{mm}$, respectively, and these values were similar with those for the BMS film containing sorbitol only as a control (Tables 1-3), suggesting that Tween 80 used as a surfactant in this study did not affect the physical and optical properties of the BMS films. 
Table 1. Physical properties of the BMS films containing BO.

\begin{tabular}{ccc}
\hline Borage Oil (\%) & Tensile Strength $\mathbf{( M P a )}$ & Elongation at Break (\%) \\
\hline 0 & $9.46 \pm 0.38^{\mathrm{a}}$ & $82.49 \pm 2.95^{\mathrm{e}}$ \\
0.2 & $6.99 \pm 0.24^{\mathrm{b}}$ & $85.74 \pm 4.34^{\mathrm{d}, \mathrm{e}}$ \\
0.4 & $6.54 \pm 0.40^{\mathrm{c}}$ & $86.38 \pm 1.46^{\mathrm{d}}$ \\
0.6 & $5.61 \pm 0.13^{\mathrm{d}}$ & $90.65 \pm 2.83^{\mathrm{c}}$ \\
0.8 & $4.87 \pm 0.22^{\mathrm{e}}$ & $94.48 \pm 2.71^{\mathrm{b}}$ \\
1.0 & $4.69 \pm 0.14^{\mathrm{e}}$ & $103.87 \pm 2.16^{\mathrm{a}}$ \\
\hline
\end{tabular}

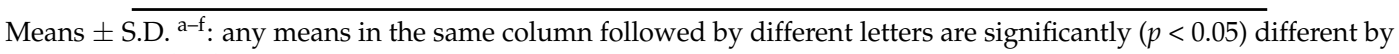
Duncan's multiple range test.

Table 2. Moisture content, water solubility, and water vapor permeability of the BMS films containing BO.

\begin{tabular}{|c|c|c|c|}
\hline Borage Oil (\%) & Moisture Content (\%) & Water Solubility (\%) & $\begin{array}{l}\text { Water Vapour Permeability } \\
\left(10^{-9} \mathrm{~g} / \mathrm{m} \cdot \mathrm{s} \cdot \mathrm{Pa}\right)\end{array}$ \\
\hline 0 & $7.41 \pm 0.26^{a}$ & $38.70 \pm 0.28^{a}$ & $4.44 \pm 0.09^{a}$ \\
\hline 0.2 & $7.00 \pm 0.29^{b}$ & $35.42 \pm 0.29^{b}$ & $4.30 \pm 0.08^{b}$ \\
\hline 0.4 & $6.73 \pm 0.24^{b, c}$ & $34.58 \pm 0.38^{c}$ & $4.11 \pm 0.12^{c}$ \\
\hline 0.6 & $6.57 \pm 0.29 \mathrm{c}, \mathrm{d}$ & $33.68 \pm 0.25^{\mathrm{d}}$ & $3.92 \pm 0.11^{d}$ \\
\hline 0.8 & $6.40 \pm 0.17^{\mathrm{d}}$ & $31.41 \pm 0.24 \mathrm{e}^{\mathrm{e}}$ & $3.83 \pm 0.14^{\mathrm{d}}$ \\
\hline 1.0 & $5.88 \pm 0.19^{\mathrm{e}}$ & $31.11 \pm 0.08^{\mathrm{e}}$ & $3.65 \pm 0.11^{\mathrm{e}}$ \\
\hline
\end{tabular}

Means \pm S.D. ${ }^{\text {a-f. }}$ : any means in the same column followed by different letters are significantly $(p<0.05)$ different by Duncan's multiple range test.

Table 3. Optical properties of the BMS films containing BO.

\begin{tabular}{ccccc}
\hline Borage Oil (\%) & $\boldsymbol{L}$ & $\boldsymbol{a}$ & $\boldsymbol{b}$ & Opacity (A/mm) \\
\hline 0 & $96.09 \pm 0.20^{\mathrm{a}}$ & $-0.23 \pm 0.02^{\mathrm{a}}$ & $3.20 \pm 0.03^{\mathrm{e}}$ & $0.55 \pm 0.04^{\mathrm{e}}$ \\
0.2 & $95.65 \pm 0.07^{\mathrm{b}}$ & $-0.35 \pm 0.01^{\mathrm{b}}$ & $3.78 \pm 0.03^{\mathrm{d}}$ & $2.84 \pm 0.02^{\mathrm{d}}$ \\
0.4 & $95.19 \pm 0.08^{\mathrm{c}}$ & $-0.46 \pm 0.03^{\mathrm{c}}$ & $4.54 \pm 0.06^{\mathrm{c}}$ & $3.57 \pm 0.08^{\mathrm{c}}$ \\
0.6 & $94.83 \pm 0.09^{\mathrm{d}}$ & $-0.50 \pm 0.02^{\mathrm{d}}$ & $5.00 \pm 0.05^{\mathrm{b}}$ & $3.64 \pm 0.08^{\mathrm{c}}$ \\
0.8 & $94.53 \pm 0.10^{\mathrm{e}}$ & $-0.56 \pm 0.03^{\mathrm{e}}$ & $5.52 \pm 0.04^{\mathrm{a}}$ & $4.62 \pm 0.22^{\mathrm{b}}$ \\
1.0 & $94.32 \pm 0.06^{\mathrm{f}}$ & $-0.59 \pm 0.03^{\mathrm{e}}$ & $5.56 \pm 0.06^{\mathrm{a}}$ & $6.26 \pm 0.19^{\mathrm{a}}$ \\
\hline
\end{tabular}

Means \pm S.D. ${ }^{\text {a-f }}$ : any means in the same column followed by different letters are significantly $(p<0.05)$ different by Duncan's multiple range test.

Table 1 shows the effect of BO incorporation into the BMS films on the TS and E values. TS decreased gradually from 9.46 to $4.69 \mathrm{MPa}$ as $\mathrm{BO}$ concentration increased up to $1.0 \%$, whereas $\mathrm{E}$ increased proportionally from $82.49 \%$ to $103.87 \%$. In particular, the addition of $1.0 \%$ BO decreased TS by $50 \%$ and increased $\mathrm{E}$ by $26 \%$, compared to the film without $\mathrm{BO}$. It appears that distribution of $\mathrm{BO}$ in the film matrix induces an obstruction between hydrophilic starch polymers and decreases the cohesiveness of the film network [23]. Moreover, fatty acid molecules in $\mathrm{BO}$ are embedded inside helical amyloses, which can reduce the interactions between starch chains and weaken the film network [13,14]. In addition, unsaturated fatty acids (USFAs), the major component of $\mathrm{BO}$, might behave as a grease for the polymers in the films, increasing E [24,25]. Similar results were reported regarding changes in TS and $\mathrm{E}$ of the films containing USFAs for sweet potato and corn starch films [13,25].

The changes in MC, WS, and WVP of the BMS films are shown in Table 2. The MC of the films decreased as $\mathrm{BO}$ was added from $0.2 \%$ to $1.0 \%$. This decrease in MC could be explained by the increase in hydrophobicity from BO. The incorporation of $\mathrm{BO}$ into starch films rearranged the amylose and amylopectin molecules, resulting in decreased affinity of amylose for water molecules by producing amylose-fatty acid complexes [26]. 
The WS of the films ranged from $38.70 \%$ for the film without $\mathrm{BO}$ to $31.11 \%$ for the film containing $1.0 \% \mathrm{BO}$. The addition of $\mathrm{BO}$ reduced the diffusion of soluble solid substances into water due to the formation of an insoluble outer layer of starch granules, which decreased the WS of the films [26]. According to Amini et al. [27], the addition of fatty acids showed similar results on the WS of basil seed gum films.

The incorporation of BO into BMS films decreased the WVP. The improved moisture barrier property indicates the formation of hydrophobic layers around the starch granules, which prevents water vapor permeation through the films [26,28]. In addition, interactions between amylose and fatty acids minimize the affinity of amylose for water molecules and reduce the hydrophilicity of the films [26]. BO contains various fatty acids including saturated fatty acids with different hydrocarbon chain lengths (palmitic, stearic, and arachidic acids) and USFAs (palmitoleic, oleic, linoleic, $\alpha$-linolenic, $\gamma$-linolenic, and eicosanoic acids) [15,29], which create a barrier against moisture permeation. Several studies have similarly reported that increasing the fatty acid concentration decreased the WVP $[14,23]$.

\subsection{Optical Properties}

The changes in colors of the films are presented in Table 3. While $L$ and $a$ values tended to decrease, the $b$ value slightly increased with increased $\mathrm{BO}$ content. This change can be explained by the dispersion of light yellow $\mathrm{BO}$ in the colorless starch film. With the increasing concentration of fatty acids or essential oils into chitosan films, similar results were reported by Silva et al., where $L$ decreased and $b$ increased [30]. Decreased $L$ value was also observed when stearic acid was added into Bambara groundnut starch films [14].

Opaque packages with light barrier properties have been applied in food packaging to protect foods from oxidation, especially photooxidation of lipids. Opacity of the BMS films proportionally increased with the addition of BO. The opacity of the BMS film with $1.0 \% \mathrm{BO}$ was more than 11-fold higher than that of the BMS film without BO. A similar result was obtained when stearic acid was incorporated into the Bambara groundnut starch film [14]. The addition of corn oil also increased the opacity of gelatin films [23].

\subsection{Antioxidant Activities}

Plant seed oils usually contain USFAs, which are sensitive to oxidation. However, these compounds are stable because of naturally existing antioxidants [31]. Tocopherols and phenolic compounds are present in borage seed, and they protect USFAs from oxidation [32,33]. Specifically, $\delta$-tocopherol and $\gamma$-tocopherol contents in borage seed oil are 52 and $659 \mathrm{mg} / \mathrm{kg}$, respectively [16].

The antioxidant activities of the BMS films increased as BO concentration increased from $0.2 \%$ to $1.0 \%$, as determined by ABTS and FRAP assays (Figure 1).

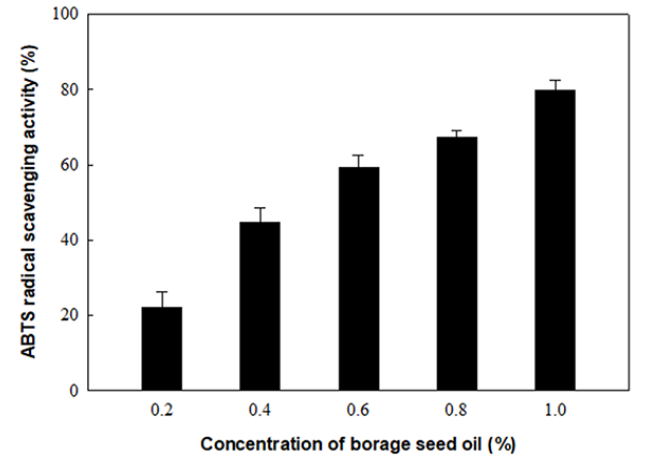

(a)

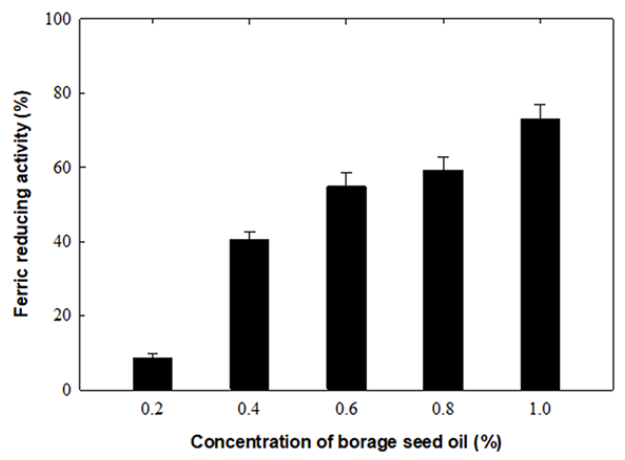

(b)

Figure 1. Antioxidant activities of the BMS films containing BO: (a) ABTS radical scavenging activity; (b) Ferric reducing activity. 
The BMS film with 1.0\% BO showed the highest antioxidant activities of $79.88 \%$ and $73.17 \%$ for ABTS radical scavenging and ferric reducing abilities, respectively. Based on these results, the natural antioxidants in $\mathrm{BO}$ can contribute to the antioxidant properties of BMS films containing BO. Similarly, the antioxidant activities of the methylcellulose films increased proportionally with increased $\alpha$-tocopherol nanocapsule concentration [34]. The incorporation of other essential oils into films similarly showed a positive correlation between antioxidant activities of the films and the essential oil content [35].

\subsection{SEM Images of BMS Films}

Micrographs of the BMS films are presented in Figure 2. The surfaces of the BMS films containing $\mathrm{BO}$ were rougher than those of the $\mathrm{BMS}$ film without $\mathrm{BO}$. In addition, $\mathrm{BO}$ aggregates were observed in the cross-sections of the films with BO. The self-clustering of fatty acids during film dehydration might form lipid aggregates, resulting in film heterogeneity [24]. Jiménez et al. observed heterogeneity in corn starch film; films incorporated with oleic acid exhibited a heterogeneous structure with the distribution of oil droplets through the cross-section [25]. Similarly, Oyeyinka et al. [14] also reported rough surfaces of Bambara groundnut starch films upon fatty acid addition. The heterogeneous structure of hydroxypropylmethyl cellulose film incorporated with fatty acids was also reported [24]. Thus, these results suggest that the microstructure of the BMS films incorporated with BO yields a film structure that is less firm and more flexible.
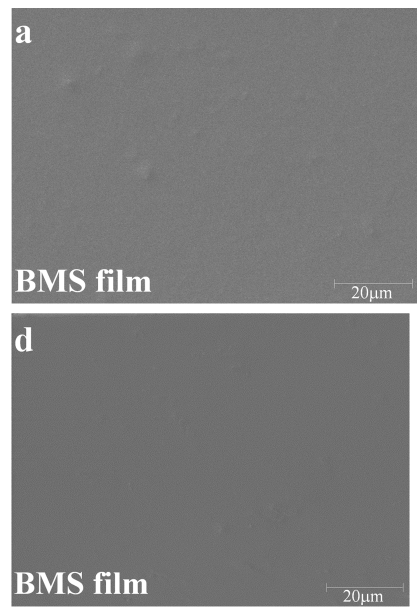
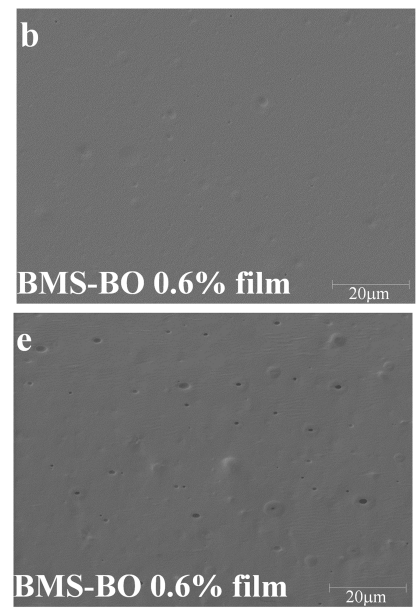
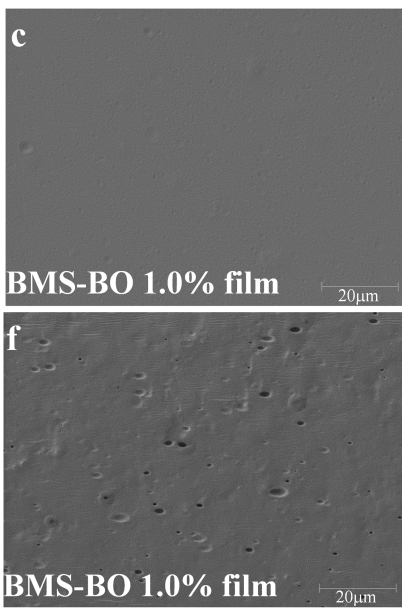

Figure 2. Surface SEM images of the (a) BMS film, (b) BMS-BO $0.6 \%$ film, and (c) BMS-BO $1.0 \%$ film. Cross-sectional SEM images of the (d) BMS film, (e) BMS-BO $0.6 \%$ film, and (f) BMS-BO $1.0 \%$ film. Magnification: $3000 \times$ and $2000 \times$ for surface and cross-section, respectively.

\subsection{Thermal Properties of Films}

The $T_{\mathrm{m}}$ and $\Delta H$ of the films are shown in Figure 3 and Table 4. DSC analysis showed that BMS films possessed one endothermic peak between 110 and $122{ }^{\circ} \mathrm{C}$, representing the melting temperatures of the films. Previously, the $T_{\mathrm{m}}$ of millet amylose-fatty acid complexes was reported to be $91.7-110{ }^{\circ} \mathrm{C}[36]$.

Table 4. Thermal properties of the BMS films containing BO. $T_{0}$ : onset temperature, $T_{\mathrm{m}}$ : melting temperature at peak, and $T_{\mathrm{C}}$ : conclusion temperature, $\Delta H$ : fusion enthalpy.

\begin{tabular}{ccccc}
\hline Borage Oil (\%) & $\boldsymbol{T}_{\mathbf{0}}\left({ }^{\circ} \mathrm{C}\right)$ & $T_{\mathrm{m}}\left({ }^{\circ} \mathrm{C}\right)$ & $T_{\mathrm{c}}\left({ }^{\circ} \mathrm{C}\right)$ & $\Delta \boldsymbol{H}(\mathrm{J} / \mathrm{g})$ \\
\hline 0 & 79.34 & 122.44 & 179.06 & 148.66 \\
1.0 & 70.60 & 110.68 & 173.28 & 116.64 \\
\hline
\end{tabular}




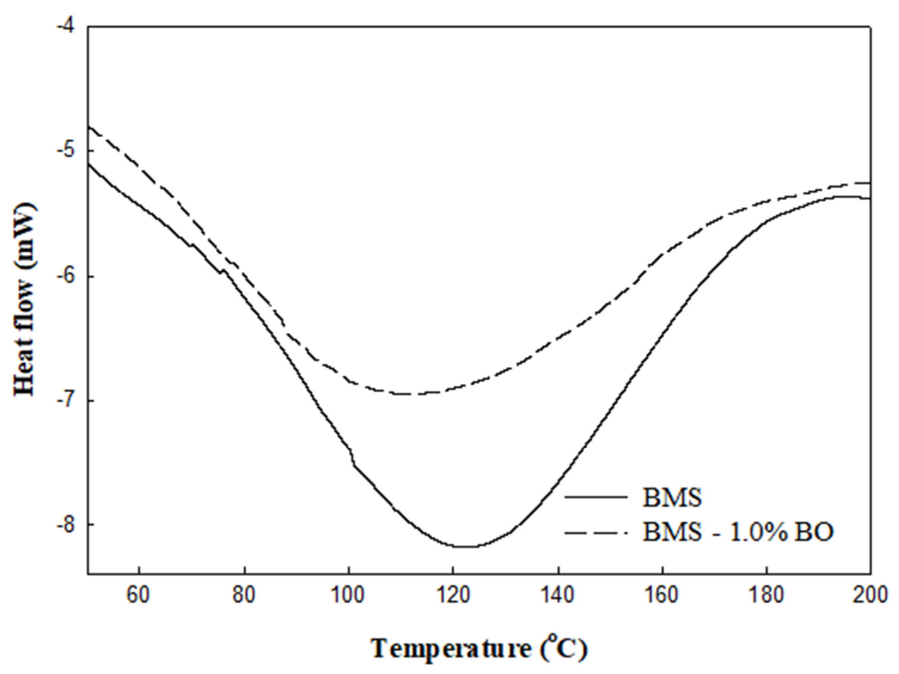

Figure 3. DSC curves of the BMS films containing BO.

It is clear that $\mathrm{BO}$ incorporation affected the $T_{\mathrm{m}}$ and $\Delta H$ of the film. In particular, the addition of BO decreased $T_{\mathrm{m}}$. The $T_{\mathrm{m}}$ of the BMS films with $1.0 \% \mathrm{BO}$ was $110^{\circ} \mathrm{C}$, lower than that of the control BMS film $\left(122^{\circ} \mathrm{C}\right)$. The decrease in $T_{\mathrm{m}}$ of the films is mainly due to the weakened network of starch and BO. It appears that BO in the film-forming solution could interact with starch polymers and occupy space in the helical amyloses, reducing the interactions between starch polymers and weakening the film network. As a result, the $\Delta H$ of the films decreased from $148.66 \mathrm{~J} / \mathrm{g}$ for the BMS film to $116.64 \mathrm{~J} / \mathrm{g}$ for the BMS films with $1.0 \%$ BO. This decrease in $\Delta H$ indicates decreased thermal stability of the BMS films containing BO. Similarly, Jaramillo et al. reported decreases in $T_{\mathrm{m}}$ and $\Delta H$ of cassava starch films supplemented with yerba mate extract [37]. In this study, the incorporation of BO decreased firmness and increased flexibility of the BMS films, and the energy required for melting the film was lesser than that required for the BMS film without $\mathrm{BO}$. Therefore, these results are consistent with the decreased TS and increased $\mathrm{E}$ of the BMS film containing BO.

\section{Conclusions}

In this study, BMS films incorporated with BO were prepared. The increasing hydrophobicity of the BMS films containing BO was demonstrated by the decreases in MC, WS, and WVP. In addition, the BMS films containing BO exhibited antioxidant activity in accordance with increased $\mathrm{BO}$ concentration. In particular, incorporation with $1.0 \% \mathrm{BO}$ into the BMS film decreased the WVP by $18 \%$, compared to that in the film without $\mathrm{BO}$. Therefore, the BMS films containing BO can be used as an antioxidant packaging material.

Acknowledgments: This work was supported by the BK21 plus program through the National Research Foundation (NRF) funded by the Ministry of Education of Korea.

Author Contributions: Thi Luyen Cao performed the experiments, analyzed the data, and wrote the first draft. So-Young Yang helped Thi Luyen Cao with discussion of experimental data. Kyung Bin Song supervised the study and prepared the final manuscript.

Conflicts of Interest: The authors declare no conflict of interest.

\section{References}

1. Khazaei, N.; Esmaiili, M.; Djomeh, Z.E.; Ghasemlou, M.; Jouki, M. Characterisation of new biodegradable edible film made from basil seed (Ocimum basilicum L.) gum. Carbohydr. Polym. 2014, 102, 199-206. [CrossRef] [PubMed]

2. Nakthong, N.; Wongsagonsup, R.; Amornsakchai, T. Characteristics and potential utilization of starch from pineapple. Ind. Crops Prod. 2017, 105, 74-82. [CrossRef] 
3. Piñeros-Hernandez, D.; Medina-Jaramillo, C.; López-Córdoba, A.; Goyanes, S. Edible cassava starch films carrying rosemary antioxidant extracts for potential use as active food packaging. Food Hydrocoll. 2017, 63, 488-495. [CrossRef]

4. Lee, J.H.; Yang, H.J.; Lee, K.Y.; Song, K.B. Physical properties and application of a red pepper seed meal protein composite film containing oregano oil. Food Hydrocoll. 2016, 55, 136-143. [CrossRef]

5. López, O.V.; Versino, F.; Villar, M.A.; García, M.A. Agro-industrial residue from starch extraction of Pachyrhizus ahipa as filler of thermoplastic corn starch films. Carbohydr. Polym. 2015, 134, 324-332. [CrossRef] [PubMed]

6. Sood, S.; Khulbe, R.K.; Gupta, A.K.; Agrawal, P.K.; Upadhyaya, H.D.; Bhatt, J.C. Barnyard millet-A potential food and feed crop of future. Plant Breed. 2015, 134, 135-147. [CrossRef]

7. Chandra, D.; Chandra, S.; Pallavi; Sharma, A.K. Review of finger millet (Eleusin coracana (L.) Gaertn): A power house of health benefiting nutrients. Food Sci. Hum. Wellness 2016, 5, 149-155. [CrossRef]

8. Kim, J.Y.; Jang, K.C.; Park, B.R.; Han, S.I.; Choi, K.J.; Kim, S.Y.; Oh, S.H.; Ra, J.E.; Ha, T.J.; Lee, J.H.; et al. Physicochemical and antioxidative properties of selected Barnyard millet (Echinochloa utilis) species in Korea. Food Sci. Biotechnol. 2011, 20, 461-469. [CrossRef]

9. Krishnakumari, S.; Thayumanavan, B. Content of starch and sugars and in vitro digestion of starch by $\alpha$-amylase in five minor millets. Plant Foods Hum. Nutr. 1995, 48, 327-333. [CrossRef] [PubMed]

10. Jaybhaye, R.V.; Pardeshi, I.L.; Vengaiah, P.C.; Srivastav, P.P. Processing and technology for millet based food products: A review. J. Ready Eat Food 2014, 1, 32-48.

11. Kumari, S.K.; Thayumanavan, B. Characterisation of starches of proso, foxtail, barnyard, kodo, and little millets. Plant Foods Hum. Nutr. 1998, 53, 47-56. [CrossRef]

12. Weiwei, L.; Juan, X.; Beijiu, C.; Suwen, Z.; Qing, M.; Huan, M. Anaerobic biodegradation, physical and structural properties of normal and high-amylose maize starch films. Int. J. Agric. Biol. Eng. 2016, 9, 184-193.

13. Liu, P.; Sun, S.; Hou, H.; Dong, H. Effects of fatty acids with different degree of unsaturation on properties of sweet potato starch-based films. Food Hydrocoll. 2016, 61, 351-357. [CrossRef]

14. Oyeyinka, S.A.; Singh, S.; Amonsou, E.O. Physicochemical and mechanical properties of bambara groundnut starch films modified with stearic acid. J. Food Sci. 2017, 82, 118-123. [CrossRef] [PubMed]

15. Mhamdi, B.; Wannes, W.A.; Bourgou, S.; Marzouk, B. Biochemical characterisation of borage (Borago officinalis L.) seeds. J. Food Biochem. 2009, 33, 331-341. [CrossRef]

16. Khan, M.A.; Shahidi, F. Photooxidative stability of stripped and non-stripped borage and evening primrose oils and their emulsions in water. Food Chem. 2002, 79, 47-53. [CrossRef]

17. Kamal-Eldin, A.; Appelqvist, L.A. The chemistry and antioxidant properties of tocopherols and tocotrienols. Lipids 1996, 31, 671-701. [CrossRef] [PubMed]

18. Yang, H.J.; Lee, J.H.; Won, M.; Song, K.B. Antioxidant activities of distiller dried grains with soluble as protein films containing tea extracts and their application in the packaging of pork meat. Food Chem. 2016, 196, 174-179. [CrossRef] [PubMed]

19. Song, N.B.; Jo, W.S.; Song, H.Y.; Chung, K.S.; Won, M.; Song, K.B. Effect of plasticizers and nano-clay content on the physical properties of chicken feather protein composite films. Food Hydrocoll. 2013, 31, 340-345. [CrossRef]

20. Kim, H.; Yang, H.J.; Lee, K.Y.; Beak, S.E.; Song, K.B. Characterization of red ginseng residue protein films incorporated with hibiscus extract. Food Sci. Biotechnol. 2017, 26, 369-374. [CrossRef]

21. Da Silva, A.C.; Jorge, N. Bioactive compounds of the lipid fractions of agro-industrial waste. Food Res. Int. 2014, 66, 493-500. [CrossRef]

22. Lee, J.H.; Lee, J.; Song, K.B. Development of a chicken feet protein film containing essential oils. Food Hydrocoll. 2015, 46, 208-215. [CrossRef]

23. Sahraee, S.; Milani, J.M.; Ghanbarzadeh, B.; Hamishehkar, H. Effect of corn oil on physical, thermal, and antifungal properties of gelatin-based nanocomposite films containing nano chitin. LWT Food Sci. Technol. 2017, 76, 33-39. [CrossRef]

24. Jiménez, A.; Fabra, M.J.; Talens, P.; Chiralt, A. Effect of lipid self-association on the microstructure and physical properties of hydroxypropyl-methylcellulose edible films containing fatty acids. Carbohydr. Polym. 2010, 82, 585-593. [CrossRef]

25. Jiménez, A.; Fabra, M.J.; Talens, P.; Chiralt, A. Effect of re-crystallization on tensile, optical and water vapour barrier properties of corn starch films containing fatty acids. Food Hydrocoll. 2012, 26, 302-310. [CrossRef] 
26. Putseys, J.A.; Lamberts, L.; Delcour, J.A. Amylose-inclusion complexes: Formation, identity and physico-chemical properties. J. Cereal Sci. 2010, 51, 238-247. [CrossRef]

27. Amini, A.M.; Razavi, S.M.A.; Zahedi, Y. The influence of different plasticisers and fatty acids on functional properties of basil seed gum edible film. Int. J. Food Sci. Technol. 2015, 50, 1137-1143. [CrossRef]

28. Richardson, G.; Langton, M.; Bark, A.; Hermansson, A.M. Wheat starch gelatinization-The effects of sucrose, emulsifier and the physical state of the emulsifier. Starch 2003, 55, 150-161. [CrossRef]

29. Eskin, N.A.M. Borage and evening primrose oil. Eur. J. Lipid Sci. Technol. 2008, 110, 651-654. [CrossRef]

30. Silva, M.F.; Lopes, P.S.; Da Silva, C.F.; Yoshida, C.M.P. Active packaging material based on buriti oil-Mauritia flexuosa L.f. (Arecaceae) incorporated into chitosan films. J. Appl. Polym. Sci. 2016, 133. [CrossRef]

31. Wettasinghe, M.; Shahidi, F. Antioxidant and free radical-scavenging properties of ethanolic extracts of defatted borage (Borago officinalis L.) seeds. Food Chem. 1999, 67, 399-414. [CrossRef]

32. Asadi-Samani, M.; Bahmani, M.; Rafieian-Kopaei, M. The chemical composition, botanical characteristic and biological activities of Borago officinalis: A review. Asian Pac. J. Trop. Med. 2014, 7, 22-28. [CrossRef]

33. Smyk, B. Singlet oxygen autoxidation of vegetable oils: Evidences for lack of synergy between $\beta$-carotene and tocopherols. Food Chem. 2015, 182, 209-216. [CrossRef] [PubMed]

34. Noronha, C.M.; De Carvalho, S.M.; Lino, R.C.; Barreto, P.L.M. Characterisation of antioxidant methylcellulose film incorporated with $\alpha$-tocopherol nanocapsules. Food Chem. 2014, 159, 529-535. [CrossRef] [PubMed]

35. Gallego, M.G.; Gordon, M.H.; Segovia, F.; Pablos, M.P.A. Gelatine-based antioxidant packaging containing Caesalpinia decapetala and Tara as a coating for ground beef patties. Antioxidants 2016, 5, 10. [CrossRef] [PubMed]

36. Gaffa, T.; Yoshimoto, Y.; Hanashiro, I.; Honda, O.; Kawasaki, S.; Takeda, Y. Physicochemical properties and molecular structures of starches from millet (Pennisetum typhoides) and sorghum (Sorghum bicolor L. Moench) cultivars in Nigeria. Cereal Chem. 2004, 81, 255-260. [CrossRef]

37. Jaramillo, C.M.; Gutiérrez, T.J.; Goyanes, S.; Bernal, C.; Famá, L. Biodegradability and plasticizing effect of yerba mate extract on cassava starch edible films. Carbohydr. Polym. 2016, 151, 150-159. [CrossRef] [PubMed]

(C) 2017 by the authors. Licensee MDPI, Basel, Switzerland. This article is an open access article distributed under the terms and conditions of the Creative Commons Attribution (CC BY) license (http:/ / creativecommons.org/licenses/by/4.0/). 